\title{
Detection and quantification of infectious hypodermal and hematopoietic necrosis virus in penaeid shrimp by real-time PCR
}

\author{
Kathy F. J. Tang*, Donald V. Lightner \\ Department of Veterinary Science and Microbiology, University of Arizona, Tucson, Arizona 85721, USA
}

\begin{abstract}
A real-time PCR method using a fluorogenic 5' nuclease assay and a PE Applied Biosystems GeneAmp 5700 sequence detector was developed to detect infectious hypodermal and hematopoietic necrosis virus (IHHNV) in penaeid shrimp. A pair of PCR primers to amplify an $81 \mathrm{bp}$ DNA fragment and a fluorogenic probe (TaqMan probe) were selected from ORF1 (open reading frame 1) of the IHHNV genome. The primers and TaqMan probe used in this assay were shown to be specific for IHHNV and did not react with either hepatopancreatic parvovirus (HPV), white-spot syndrome virus (WSSV), or shrimp DNA. A plasmid, pIHHNV-P4, containing the target IHHNV sequence was constructed and used as a positive control. The concentration of pIHHNV-P4 was determined through spectrophotometric analysis and the plasmid was used for quantitative studies. This real-time PCR assay had a detection limit of 10 copies and a log-linear range up to $5 \times 10^{7}$ copies of IHHNV DNA. The assay was then used to quantify IHHNV in infected shrimp collected from 5 locations: Hawaii, Panama, Mexico, Guam, and the Philippines. The quantitative analysis showed that wild-caught, large juvenile Penaeus stylirostris collected from the Gulf of California (Mexico) in 1996 were naturally infected with IHHNV and contained up to $10^{9}$ copies of IHHNV $\mu^{-1}$ of DNA. Similar quantities of IHHNV were detected in hatchery-raised, small juvenile $P$. stylirostris collected from Guam in 1995 and in farm-raised, post-larval P. monodon from the Philippines in 1996. Laboratory-infected $P$. stylirostris contained approximately $10^{8}$ copies of IHHNV $31 \mathrm{~d}$ after being fed with IHHNV-infected shrimp tissue. In contrast, individuals of Super Shrimp ${ }^{\circledR}$, a line of P. stylirostris selected for IHHNV resistance, showed no signs of infection $32 \mathrm{~d}$ after ingesting IHHNV-infected shrimp tissue. Laboratory-infected $P$. vannamei also contained approximately $10^{8}$ copies of IHHNV $30 \mathrm{~d}$ after being fed infected shrimp tissue. A time-course study of IHHNV replication in juvenile $P$. vannamei showed that the doubling time in the exponential growth phase was approximately $22 \mathrm{~h}$.
\end{abstract}

KEY WORDS: IHHNV $\cdot$ Penaeid shrimp $\cdot$ Real-time PCR $\cdot$ TaqMan

\section{INTRODUCTION}

Infectious hypodermal and hematopoietic necrosis virus (IHHNV) is one of the major causes of disease in cultured penaeid shrimp. This virus was first detected in juvenile Penaeus stylirostris from Hawaii in 1981 (Lightner et al. 1983a,b), where it caused mortalities of up to $90 \%$. Since then, the virus has been detected in other life stages of a number of penaeids in the Ameri-

*E-mail: fengjyu@u.arizona.edu cas, Oceania, east and southeast Asia (Lightner 1996). Even though this is an extremely virulent virus, individuals with asymptomatic IHHNV infections have been found among farm-raised P. vannamei (Lightner et al. 1983a, Kalagayan et al. 1991), within a highly selected line of $P$. stylirostris SPR43 (Weppe et al. 1992), and in wild-caught $P$. stylirostris (MoralesCovarrubias et al. 1999, Pantoja et al. 1999).

IHHNV is a small, icosahedral, non-enveloped virus containing a single-stranded linear DNA genome approximately $4.1 \mathrm{~kb}$ in length (Bonami et al. 1990, Mari 
et al. 1993). Based on size, morphology and biochemical structure, IHHNV is considered to be a member of the family Parvoviridae (Bonami et al. 1990). Nearly $100 \%$ of the IHHNV genomic sequence and its 3 large open reading frames (ORF1, 2 and 3) have been determined (Nunan et al. 2000, GenBank AF218266). Among them, the ORF1 (nucleotide 816 to nucleotide 2813) encodes a 666 amino acid polypeptide, and this is predicted to be a non-structural protein based upon its degree of homology with Aedes albopictus densovirus and with Aedes densonucleosis virus.

Determination of the number of viral genomes in infected animals has become one of the most important means of monitoring shrimp diseases, and it is especially useful for detecting viral infections in asymptomatic individuals. Progress in quantification of shrimp viruses has been hampered by the lack of a continuous cell culture system for shrimp; however, real-time PCR allows the quantification of IHHNV genome in individual shrimp without the need for cell culture.

The real-time PCR method is based on the addition of a fluorogenic (TaqMan) probe in a 5' nuclease assay (Gibson et al. 1996, Heid et al. 1996). The TaqMan probe is fluorescently labeled with a reporter dye at the $5^{\prime}$ end and a quencher dye at the 3 ' end (Holland et al. 1991). The quencher suppresses the fluorescence emitted by the reporter through Forster resonance energy transfer (FRET) (Forster 1948, Lakowics 1983). During the PCR, the Taq polymerase extends the new DNA from its upstream primer, and its 5 '-3' exonuclease activity cleaves the reporter dye from the TaqMan probe, which hybridizes to the internal portion of the template DNA. Hydrolysis of the reporter dye increases fluorescence as the quenching effect is destroyed. The Taq polymerase synthesizes amplicons, which are available for probe binding, and the fluorescence increases in proportion to the number of amplicons generated. A major feature of real-time PCR is the measurement of DNA amplification at each cycle, instead of accumulated amplification at the completion of cycling. The measurement is made during the exponential phase of PCR, which is more reproducible than measurement of the end products of the reaction.

Real-time PCR measures fluorescence intensity. This eliminates post-PCR processing, greatly increases throughput, and reduces the risk of contamination. In this report, we describe the development of a real-time PCR assay for IHHNV and the application of this method to analysis of IHHNV-infected penaeid shrimp.

\section{MATERIALS AND METHODS}

Shrimp and viruses. We used 6 archived cases of IHHNV-infected shrimp, all stored at $-80^{\circ} \mathrm{C}$, in a quan- titative study to determine the viral load in the tissues. Cases were coded for year $(\mathrm{xx})$ of collection and sample number (y), for example (19xx/y). Case 1 (1996/ 1-5) consisted of 5 wild-caught, large (8 g) juvenile Penaeus stylirostris that were collected from Gulf of California in 1996. Case 2 (1995/1 \& 2) included small (1 g) juvenile $P$. stylirostris that were obtained from a hatchery on Guam in 1995. These shrimp were originally from Mexico; they were quarantined in Hawaii and then sent to Guam. Case 3 (1996/6 \& 7) consisted of samples of farm-raised, postlarval $P$. monodon sent from the Philippines to the University of Arizona in 1996. Case $4(2000 / 1)$ was a sample of 3 juvenile $P$. stylirostris $(1 \mathrm{~g})$ that were fed with IHHNV-infected tissue (Mexico-isolate) for $3 \mathrm{~d}$ and sampled at $31 \mathrm{~d}$ post feeding (p.f.). Case 5 (1999/1) involved a sample of 3 juvenile Super Shrimp ${ }^{\circledR}$ (1 g, Maritech Inc., AZ, USA) that had been fed with IHHNV-infected tissue (Panama isolate) for $3 \mathrm{~d}$ and sampled after $32 \mathrm{~d}$. Case 6 was a time-course study of IHHNV-infection in a population (30 shrimp, $2 \mathrm{~g}$ ) of juvenile $P$. vannamei. Shrimp were fed with IHHNV-infected tissue (Panama isolate) for $2 \mathrm{~d}$ and then 1 shrimp was sampled at each of various time points after feeding. A sample (1999/2) consisted of 3 shrimp that were taken at Day 30 . The laboratory-infected shrimp were maintained at $27^{\circ} \mathrm{C}$. In all cases, the penaeid nomenclature used in this paper follows Holthius (1980).

HPV (hepatopancreatic parvovirus) virions were isolated from infected shrimp tissue (Korean isolate) and purified according to Bonami et al. (1995). IHHNV virions (Hawaii isolate) were purified according to a protocol developed by Bonami et al. (1990). WSSV (white spot syndrome virus)-infected tissue was prepared by laboratory-infection of SPF (specific pathogen-free) Penaeus vannamei (Carr et al. 1994) with a WSSV inoculum (Thailand isolate).

DNA extraction. For assay of juvenile shrimp, a $0.03 \mathrm{~g}$ tissue sample was removed from either heads, gills, or pleopods. For post-larvae (PL), whole shrimp were used. DNAzol reagent (Life Technology, MD, USA) was used to extract total DNA. In accordance with the manufacturer's recommendations, the samples of extracted DNA were suspended in $100 \mu \mathrm{l}$ of $\mathrm{NaOH}(8 \mathrm{mM})$ and then neutralized to $\mathrm{pH} 8.0$ with $11.5 \mu$ l of HEPES $(0.1 \mathrm{M})$. The concentration of extracted DNA was determined by measuring optical density, $\mathrm{OD}_{260}$, with a spectrophotometer, GeneQuant II (Amersham Pharmacia Biotech, NJ, USA).

PCR primers and probe. The PCR primers and TaqMan probe for the detection of IHHNV were selected from a region of the IHHNV genomic sequence (GenBank AF218266) that encodes for non-structural protein. The primers and probe sequences were designed with Primer Express software (PE Applied Biosystems, 
Foster City, CA, USA). The upstream (IHHNV1608F) and downstream (IHHNV1688R) primer sequences were: 5' ${ }^{-T A C}$ TCC GGA CAC CCA ACC A-3' and 5'GGC TCT GGC AGC AAA GGT AA-3', respectively. The TaqMan probe (5'-ACC AGA CAT AGA GCT ACA ATC CTC GCC TAT TTG-3'), which corresponds to the region from nucleotide 1632 to 1664 , was synthesized and labeled with fluorescent dyes 5-carboxyfluoroscein (FAM) on the $5^{\prime}$ end and $\mathrm{N}, \mathrm{N}, \mathrm{N}^{\prime}, \mathrm{N}^{\prime}$-tetramethyl-6-carboxyrhodamine (TAMRA) on the $3^{\prime}$ end. For the TaqMan assay we used the TaqMan Universal PCR Master Mix containing AmpliTaq Gold DNA polymerase, AmpErase UNG (uracil-N-glycosylase), dNTPs with dUTP, passive reference, and optimized buffer components (PE Applied Biosystems). A sample of $10 \mathrm{ng}$ of DNA was added to a PCR mixture containing $0.3 \mu \mathrm{M}$ of each primer and $0.15 \mu \mathrm{M}$ of TaqMan probe in a volume of $25 \mu$ l. Amplification was performed with the following profile: 2 min reaction for AmpErase UNG at $50^{\circ} \mathrm{C}$ and subsequent activation of the AmpliTaq for $10 \mathrm{~min}$ at $95^{\circ} \mathrm{C}, 40$ cycles of $15 \mathrm{~s}$ at $95^{\circ} \mathrm{C}$ and $1 \mathrm{~min}$ at $60^{\circ} \mathrm{C}$ were carried out with the GeneAmp 5700 (PE Applied Biosystems). Real-time fluorescence measurements were taken with a built in chargecoupled device (CCD) camera, and a threshold cycle (Ct) value was set to be above the baseline that begins to detect the increase in signal associated with an exponential increase of PCR product. Samples were defined as negative if the $\mathrm{Ct}$ values exceeded 40 cycles. The quantity of each sample was determined by GeneAmp 5700 Sequence Detection System software (SDS 1.0). Each sample was tested in duplicate and the result was considered positive only if both replicates were positive. To confirm the TaqMan assay results, an aliquot of PCR product was subjected to electrophoresis on a $4 \%$ EtBr-agarose gel and photographed.

Construction and cloning of a positive control. A DNA fragment containing $757 \mathrm{bp}$ of IHHNV nonstructural protein (nucleotide 1215 to 1971) was cloned in the pGEM-T-Easy vector (Promega, Madison, WI, USA) and designated as pIHHNV-P4. The plasmid was purified with alkaline lysis and polyethylene glycol-NaCl precipitation (Paithankar \& Prasad 1991) and sequenced to confirm that it contained the sequence for PCR primers and TaqMan probe. The concentration of pIHHNV-P4 was then determined by measurement of OD at $260 \mathrm{~nm}$ and confirmed with agarose gel electrophoresis. The size of pIHHNV-P4 was $3.777 \mathrm{~kb}$; this is equivalent to $2.455 \times 10^{6} \mathrm{Da}$. Multiplying this value by the conversion factor $1.66 \times 10^{-24}$ gives $4.07 \times 10^{-18} \mathrm{~g}$. Therefore, $1 \mathrm{ng}\left(10^{-9} \mathrm{~g}\right)$ of plasmid contains $2.45 \times 10^{8}$ copies. This value was used to determine the copy numbers of the standards.

\section{RESULTS \\ Selection of primers and TaqMan probe for real-time IHHNV PCR}

In order to detect IHHNV isolated from various geographic regions, a conserved region of the IHHNV genome was selected to permit binding of both the PCR primers and the TaqMan probe. ORF1, which presumably encodes for the non-structural protein, was chosen as the target region. The sequences of primers IHHNV1608F/1688R and the internal TaqMan probe used were determined with Primer Express software, and these were used to amplify a $81 \mathrm{bp}$ amplicon in real-time PCR. The target sequence is from nucleotide 1608 to 1688 within the IHHNV genome. We sequenced a portion of the IHHNV genome, nucleotide 1215 to 1971, which contains the target sequence for real-time IHHNV PCR. The DNA sequence of this fragment was shown to be identical with IHHNV collected from 3 geographic regions: Hawaii (in 1987), Panama (in 1996), and Mexico (in 1999) (data not shown).

\section{Specificity of real-time IHHNV PCR}

To determine if this real-time IHHNV PCR assay can be used to detect IHHNV DNA, it was first applied for the detection of CsCl-purified IHHNV (Hawaii isolate) virions. The result was positive and the $\mathrm{Ct}$ value was 13.28 (Fig. 1A). Ct values are predictive of the quantity of template (Heid et al. 1996). The higher the starting copy number of the IHHNV DNA, the earlier a significant increase in fluorescence is observed, and the lower the $\mathrm{Ct}$ value. Detection with the total DNA extracted from IHHNV-infected Penaeus stylirostris (Mexico isolate) was also positive and the $\mathrm{Ct}$ value was 17.57, indicating less IHHNV DNA in the sample than with the purified virions. The real-time PCR appears to be specific to IHHNV DNA; it does not detect HPV virions, DNA extracted from WSSV-infected P. vannamei, or DNA extracted from SPF $P$. vannamei. The Ct values for these samples were 40 . These results were confirmed by observing the real-time PCR products after agarose gel electrophoresis (Fig. 1B).

\section{Sensitivity of real-time IHHNV PCR}

To determine the sensitivity of real-time IHHNV PCR, a plasmid, pIHHNV-P4, which contains the target sequence, was used as a standard. Its concentration was determined and expressed as number of molecules per reaction. The preliminary quantification showed that the number of copies detected varied with the 

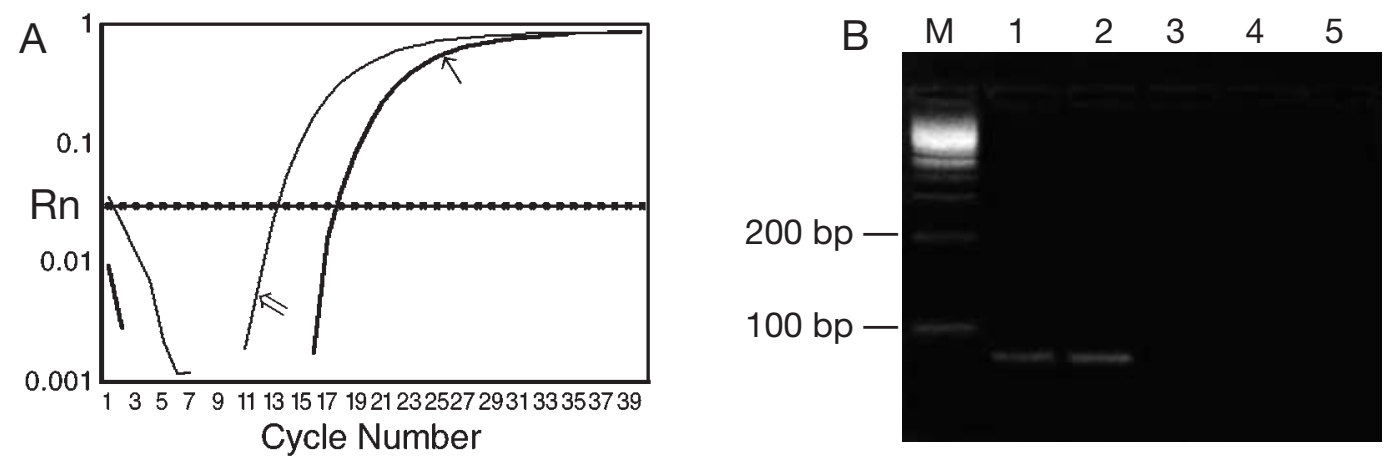

Fig. 1. Specificity of real-time IHHNV PCR. (A) The amplification plots for CsCl-purified IHHNV $(\Leftarrow$ ) and extracted IHHNV DNA $(\leftarrow)$. Rn (normalized reporter) is the emission of the reporter. The Rn between cycle 6 and 11, value of 0.03 , was set as background fluorescence in this experiment, the fluorescence generated before cycle 6 was considered as noise. (B) Gel electrophoresis of real-time PCR products. Lane M: 100 bp DNA ladder; lane 1: CsCl-purified IHHNV virions; lane 2: DNA extracted from IHHNV-infected Penaeus vannamei; lane 3: CsCl-purified HPV virions; lane 4: DNA extracted from WSSV-infected P. vannamei; lane 5: DNA extracted from SPF P. vannamei. Both WSSV and HPV templates could be amplified through PCR with their specific primers

amount of total DNA used in the PCR. When a quantity of $1 \times 10^{6}$ copies of the pIHHNV-P4 was mixed with shrimp DNA to a final concentration of $10 \mathrm{ng}$, the number of copies detected decreased to $0.9 \times 10^{6}$, and it further declined to $49 \%$ if $100 \mathrm{ng}$ of total DNA was present in the mixture (Table 1). The commercial TaqMan PCR mixture is optimized by the manufacturer to use 10-100 ng of template DNA per $50 \mu \mathrm{l}$ of reaction. We used $10 \mathrm{ng}$ of total DNA for each of the quantitative studies. The standards were prepared by adding shrimp DNA to a final quantity of $10 \mathrm{ng}$ DNA per $25 \mu \mathrm{l}$ reaction. By testing from 5 to $5 \times 10^{7}$ copies of pIHHNV-P4 plasmid, we determined that the limit of detection of the assay is 10 copies of IHHNV DNA (Fig. 2). The average coefficient of regression of the standard curve was 0.99

\section{Quantitative detection of IHHNV in penaeid shrimp}

The real-time PCR was used to detect and quantify IHHNV from 6 archived cases of IHHNV-infected penaeid shrimp stored at the University of Arizona.

Table 1. Effect of the quantity of total DNA on the IHHNV copy number determined by real-time PCR. A quantity of $10^{6}$ copies of pIHHNV-P4 plasmid DNA was added with various quantities of shrimp DNA to a final concentration of either 10,50, or $100 \mathrm{ng}$ per $25 \mu \mathrm{l}$ of reaction and used in realtime PCR

\begin{tabular}{|cc|}
\hline Total DNA (ng) & IHHNV copy number \\
\hline 0 & $1 \times 10^{6}$ \\
10 & $0.90 \times 10^{6}$ \\
50 & $0.78 \times 10^{6}$ \\
100 & $0.49 \times 10^{6}$ \\
\hline
\end{tabular}

Wild-caught Penaeus stylirostris (1996/1-5): These large juveniles from the Gulf of California showed no significant mortalities while being maintained in the laboratory. However, they were known, from dot-blot hybridization analysis of hemolymph samples, to be highly infected with IHHNV (data not shown). DNA extracted from the gills and pleopods of each of 5 shrimp proved to be IHHNV-positive with estimated quantities of IHHNV DNA of $3.9 \times 10^{8}$ to $1.2 \times$ $10^{9}$ copies $\mu \mathrm{g}^{-1}$ of DNA (Table 2 ).

Hatchery-raised Penaeus stylirostris (1995/1 \& 2): The small juveniles from the government hatchery on Guam suffered high mortalities and were later found, through histological analysis, to be infected with IHHNV (Dr J. Brock, Department of Land and Natural Resources, Hawaii, pers. comm.). Two DNA samples extracted from soft-tissues of the heads were analyzed

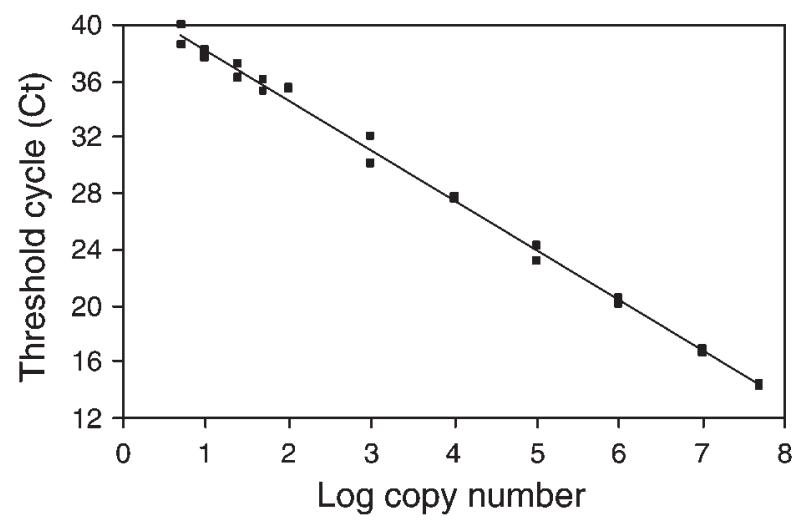

Fig. 2. Standard curve of the IHHNV copy number versus Ct (threshold cycle) value. Purified pIHHNV-P4 plasmid was serially diluted from $5 \times 10^{7}$ to 5 copies and used as templates in real-time PCR. The resulting Ct values are plotted against the logarithm of their respective copy numbers 
by real-time PCR and shown to be positive for IHHNV. The quantities of IHHNV were: $4.5 \times 10^{8}$ and $1.2 \times$ $10^{9} \mathrm{\mu g}^{-1}$ of DNA (Table 2).

Farm-raised Penaeus monodon PLs (1996/6 \& 7): This group of postlarval shrimp from the Philippines began to show mortalities immediately after arrival at the University of Arizona and were found, by dot-blot hybridization, to be infected with IHHNV (data not shown). Two DNA samples extracted from 5 PLs each were analyzed by real-time PCR and confirmed to be positive for IHHNV at 1.5 to $1.6 \times 10^{9}$ copies $\mu g^{-1}$ of DNA (Table 2).

Laboratory-infected Penaeus stylirostris (2000/1): Juveniles that were experimentally infected by feeding them IHHNV-infected tissue (Mexico isolate) for $3 \mathrm{~d}_{\text {; }}$ shrimp were sampled at Day 31 p.f. DNA was extracted from pleopods pooled from 3 shrimp and assayed with real-time PCR. The quantity of IHHNV DNA was $2.2 \times 10^{8}$ copies $\mu g^{-1}$ of DNA (Table 2 ).

Laboratory-infected Super Shrimp ${ }^{\circledR}$, a selected line of Penaeus stylirostris (1999/1): Juvenile Super Shrimp ${ }^{\circledR}$, an IHHNV-resistant line of $P$. stylirostris, that had been fed with IHHNV-infected tissue (Panama isolate) and sampled after $32 \mathrm{~d}$ were apparently not infected. No IHHNV DNA was detected in real time PCR analysis of extracted DNA from the soft tissues of the heads (Table 2).

Laboratory-infected Penaeus vannamei (1999/2): Juveniles fed with IHHNV-infected tissue (Panama isolate) and sampled at various time points after exposure were shown by PCR analysis to be infected with
IHHNV. The time-course of the infection is shown in Fig. 3. The change in the number of viral copies over time was characterized by a brief initial peak followed by a gradual rise to a maximum of $10^{8}$ copies $\mu^{-1}$ of DNA. The initial peak $\left(7.9 \times 10^{5}\right.$ copies $)$ was brief $(4 \mathrm{~d})$ and apparently was from the IHHNV-infected tissue fed to the shrimp. The subsequent increase in viral DNA copies indicates replication of the virus. The doubling time for IHHNV was approximately $22 \mathrm{~h}$ between Days 6 and 15 p.f., and the quantity of IHHNV in the shrimp remained relatively stable after Day 20 p.f. The quantity of IHHNV present at Day 30 p.f. was $4.6 \times 10^{8}$ copies $\mu g^{-1}$ of DNA (Table 2 ).

\section{DISCUSSION}

The 5' nuclease PCR assay in conjunction with realtime scanning and measurement is a new technique that can be used to rapidly quantify a large number of samples with high specificity and sensitivity. This technique was applied to develop a real-time PCR assay for the quantification of IHHNV genomes. This involved: (1) selection of a pair of IHHNV primers and an internal probe within a conserved region of the IHHNV genome; (2) construction of a plasmid standard containing the target sequence for quantification; (3) establishment of a linear, 7 -log, relationship between the $\mathrm{Ct}$ value and the number of copies of the standard; and (4) determination of the sensitivity of detection.

Table 2. Quantitative analysis of IHHNV by real-time PCR. Each case is coded by year of collection and sample number. p.f.: post feeding

\begin{tabular}{|c|c|c|c|c|c|}
\hline Case no. & IHHNV & Species & Origin & Tissues & Copy no. $\mu \mathrm{g}^{-1}$ DNA \\
\hline Case 1 (1996/1) & Mexico & Penaeus stylirostris & Wild-caught & $\begin{array}{l}\text { Gills } \\
\text { Pleopods }\end{array}$ & $\begin{array}{l}1.1 \times 10^{9} \\
4.2 \times 10^{8}\end{array}$ \\
\hline Case $1(1996 / 2)$ & Mexico & P. stylirostris & Wild-caught & $\begin{array}{l}\text { Gills } \\
\text { Pleopods }\end{array}$ & $\begin{array}{l}7.2 \times 10^{8} \\
1.1 \times 10^{9}\end{array}$ \\
\hline Case $1(1996 / 3)$ & Mexico & P. stylirostris & Wild-caught & $\begin{array}{l}\text { Gills } \\
\text { Pleopods }\end{array}$ & $\begin{array}{l}5.5 \times 10^{8} \\
7.7 \times 10^{8}\end{array}$ \\
\hline Case $1(1996 / 4)$ & Mexico & P. stylirostris & Wild-caught & $\begin{array}{l}\text { Gills } \\
\text { Pleopods }\end{array}$ & $\begin{array}{l}1.2 \times 10^{9} \\
8.3 \times 10^{8}\end{array}$ \\
\hline Case $1(1996 / 5)$ & Mexico & P. stylirostris & Wild-caught & $\begin{array}{l}\text { Gills } \\
\text { Pleopods }\end{array}$ & $\begin{array}{l}9.8 \times 10^{8} \\
3.9 \times 10^{8}\end{array}$ \\
\hline Case $2(1995 / 1)$ & Guam & P. stylirostris & Hatchery & Heads & $1.2 \times 10^{9}$ \\
\hline Case $2(1995 / 2)$ & Guam & P. stylirostris & Hatchery & Heads & $4.5 \times 10^{8}$ \\
\hline Case $3(1996 / 6)$ & Philippines & P. monodon & Farm & Whole PLs & $1.6 \times 10^{9}$ \\
\hline Case $3(1996 / 7)$ & Philippines & P. monodon & Farm & Whole PLs & $1.5 \times 10^{9}$ \\
\hline Case $4(2000 / 1)$ & Mexico & P. stylirostris & $\begin{array}{l}\text { Lab infection, } \\
\text { Day } 31 \text { p.f. }\end{array}$ & Pleopods & $2.2 \times 10^{8}$ \\
\hline Case 5 (1999/1) & Panama & $\begin{array}{l}\text { P. stylirostris } \\
\text { (Super Shrimp }^{\circledR} \text { ) }\end{array}$ & $\begin{array}{l}\text { Lab infection, } \\
\text { Day } 32 \text { p.f. }\end{array}$ & Heads & Not detected \\
\hline Case $6(1999 / 2)$ & Panama & P. vannamei & $\begin{array}{l}\text { Lab infection, } \\
\text { Day } 30 \text { p.f. }\end{array}$ & Heads & $4.6 \times 10^{8}$ \\
\hline
\end{tabular}




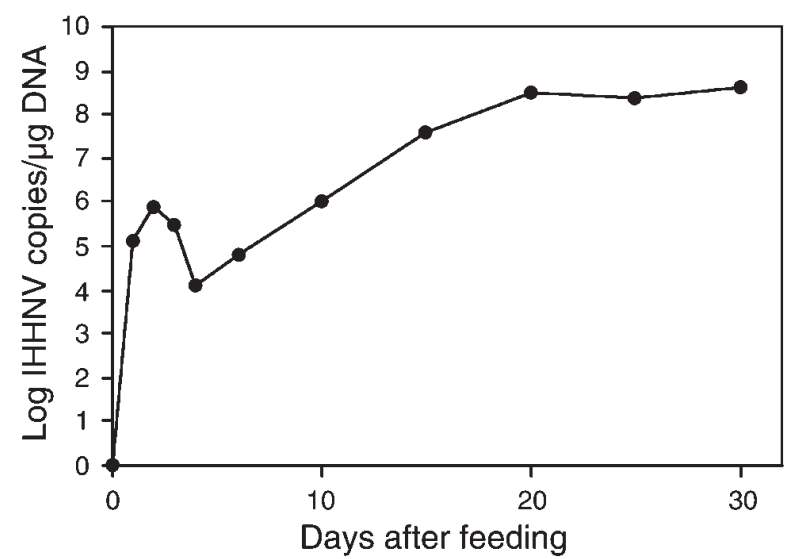

Fig. 3. Time-course of IHHNV infection in a population of juvenile Penaeus vannamei. Shrimp were fed with IHHNVinfected tissue for $2 \mathrm{~d}$ and were fed a pelletized shrimp feed thereafter. At various time points, 1 shrimp was sampled for real-time PCR analysis

This method proved to be more rapid and much more sensitive than traditional PCR. Traditional PCR usually takes $3 \mathrm{~h}$ to complete, and the sensitivity of detection is $10^{4}$ copies of IHHNV $\mu^{-1}$ DNA determined in our laboratory. The sensitivity of real-time PCR is equivalent to that of nested-PCR (Morris et al. 1996) and has the advantage of not requiring postamplification manipulation. Other quantitative PCR methods, such as competitive PCR, have narrow ranges, usually only 3 to 4 orders of magnitude with log-linearity, as compared to 7 orders of magnitude with real-time PCR. The real-time PCR greatly simplifies the quantification of IHHNV genome and allows for increased throughput.

Application of this method to detect and quantify IHHNV in various penaeid shrimp revealed new information regarding the levels of IHHNV infection. The maximum level of IHHNV in wild Penaeus stylirostris was in the order of $10^{9}$ copies $\mu g^{-1}$ of DNA. Also, $10^{9}$ copies IHHNV $\mu^{-1}$ of DNA were detected in P. monodon PLs and in juvenile P. stylirostris. In both cases high mortalities were observed. Mortalities caused by IHHNV have been reported primarily in early life stages of shrimp (PLs and small juveniles) (Lightner 1996).

The real-time PCR also showed that IHHNV was not detected in Super Shrimp ${ }^{\circledR}$ juveniles 32 d after per os challenge with IHHNV-infected tissue. Analysis with both traditional PCR and in situ hybridization showed that Super Shrimp ${ }^{\circledR}$ PLs and juveniles were not infected with IHHNV (Tang et al. 2000). This confirms that Super Shrimp ${ }^{\circledR}$ are resistant to IHHNV infection.

The time-course of IHHNV infection in the juvenile Penaeus vannamei indicated that the doubling time for IHHNV was about $22 \mathrm{~h}$. The replication of IHHNV depends on the age of host, feeding dosage, etc. Nevertheless, the doubling time of IHHNV is long compared to that of WSSV, which is estimated to be $1.9 \mathrm{~h}$ (Tang \& Lightner 2000). This may be related to the fact that parvoviruses are extremely small particles with limited genetic information and therefore highly dependent on their host cells for replication.

In the past, determination of the severity of IHHNV infection was accomplished either by histological analysis or by dot-blot hybridization. However, we recently found that histological grading does not always correlate with the level of infection (Tang \& Lightner unpubl. data). Dot-blot hybridization is time-consuming and not as sensitive as traditional PCR (Nunan et al. 2000). In contrast, real-time PCR allows for the rapid processing of large numbers of samples and is very sensitive. Therefore, real-time PCR is better suited to quantify IHHNV than the methods commonly used.

Acknowledgements. This work was supported by the Gulf Coast Research Laboratory Consortium Marine Shrimp Farming Program, CSRS, USDA, under Grant no. 99-38808-743. We thank Dr David Besselsen at the University of Arizona for kindly sharing the GeneAmp 5700 sequence detection system, Ms Bonnie Poulos and Dr Carlos Pantoja for providing purified IHHNV and HPV virions, and Dr Stephen Nelson for his assistance in editing this manuscript.

\section{LITERATURE CITED}

Bonami JR, Trumper B, Mari J, Brehelin M, Lightner DV (1990) Purification and characterization of the infectious hypodermal and hematopoietic necrosis virus of penaeid shrimps. J Gen Virol 71:2657-2664

Bonami JR, Mari J, Poulos BT, Lightner DV (1995) Characterization of hepatopancreatic parvo-like virus, a second unusual parvovirus pathogenic for penaeid shrimps. J Gen Virol 76:813-817

Carr WH, Sweeney JN, Swingle JS (1994) The Oceanic Institute's specific pathogen free (SPF) shrimp breeding program: preparations and infrastructure. In: McIlwain $T$, Pruder G (eds) US Marine Shrimp Farming Program 10th Anniversary Review. Gulf Coast Research Laboratory, Ocean Springs, Mississippi, Special Publication No. 1, p $47-54$

Forster VT (1948) Zwischenmolekulare Energiewanderung und Fluoreszenz. Ann Physics (Leipzig) 2:55-75

Gibson UE, Heid CA, Williams PM (1996) A novel method for real time quantitative RT-PCR. Genome Res 6:995-1001

Heid CA, Stevens L, Livak KJ, Williams PM (1996) Real time quantitative PCR. Genome Res 6:986-994

Holland PM, Abramson RD, Watson R, Gelfand DH (1991) Detection of specific polymerase chain reaction product by utilizing the 5 '----3' exonuclease activity of Thermus aquaticus DNA polymerase. Proc Natl Acad Sci 88: 7276-7280

Holthius LB (1980) FAO species catalogue. FAO Fisheries Synopsis No. 125, Vol 1. Shrimps and prawns of the world: an annotated catalogue of species of interest to fisheries. Food and Agricultural Organization of the United Nations, Rome 
Kalagayan G, Godin D, Kanna R, Hagino G, Sweeney J, Wyban J, Brock J (1991) IHHN virus as an etiological factor in runt-deformity syndrome of juvenile Penaeus vannamei cultured in Hawaii. J World Aquacult Soc 22: $235-243$

Lakowics JR (1983) Principles of fluorescent spectroscopy. Plenum Press, New York, p 303-339

Lightner DV (1996) A handbook of shrimp pathology and diagnostic procedures for diseases of cultured penaeid shrimp. World Aquaculture Society, Baton Rouge, LA

Lightner DV, Redman RM, Bell TA, Brock JA (1983a) Detection of IHHN virus in Penaeus stylirostris and P. vannamei imported into Hawaii. J World Maricult Soc 14:212-225

Lightner DV, Redman RM, Bell TA (1983b) Infectious hypodermal and hematopoietic necrosis, a newly recognized virus disease of penaeid shrimp. J Invertebr Pathol 42: $62-70$

Mari J, Bonami JR, Lightner DV (1993) Partial cloning of the genome of infectious hypodermal and hematopoietic necrosis virus, an unusual parvovirus pathogenic for penaeid shrimps; diagnosis of the disease using a specific probe. J Gen Virol 74:2637-2643

Morales-Covarrubias MS, Nunan LM, Lightner DV, MotaUrbina JC, Garza-Aguirre MC, Chavez-Sanchez MC (1999) Prevalence of infectious hypodermal and hematopoietic necrosis virus (IHHNV) in wild adult blue shrimp Penaeus stylirostris from the northern Gulf of California, Mexico. J Aquat Animal Health 11:296-301

Editorial responsibility: Timothy Flegel, Bangkok, Thailand and Carey Cunningham, Aberdeen, Scotland, UK
Morris T, Robertson B, Gallagher M (1996) Rapid reverse transcription-PCR detection of hepatitis C virus RNA in serum by using the TaqMan fluorogenic detection system. J Clin Microbiol 34:2933-2936

Nunan LM, Poulos BT, Lightner DV (2000) Use of polymerase chain reaction for detection of infectious hypodermal and hematopoietic necrosis virus in penaeid shrimp. Mar Biotechnol 2:319-328

Paithankar KR, Prasad KSN (1991) Precipitation of DNA by polyethylene glycol and ethanol. Nucleic Acid Res 19:1346

Pantoja CR, Lightner DV, Holtshmit KH (1999) Prevalence and geographic distribution of infectious hypodermal and hematopoietic necrosis virus (IHHNV) in wild blue shrimp Penaeus stylirostris from the Golf of California, Mexico. J Aquat Animal Health 11:23-34

Tang KFJ, Lightner DV (2000) Quantification of white spot syndrome virus DNA through a competitive polymerase chain reaction. Aquaculture 189:11-21

Tang KFJ, Durand SV, White BL, Redman RR, Pantoja CR, Lightner DV (2000) Postlarvae and juveniles of a selected line of Penaeus stylirostris are resistant to infectious hypodermal and hematopoietic necrosis virus infection. Aquaculture 190:203-210

Weppe M, Bonami JR, Lightner DV (1992) Demonstration de altas cualidades de la cepa de $P$. stylirostris (AQUACOP SPR 43) resistante al virus IHHN. In: Calderon J, Shartz L (eds) Proceedings of the 'Primero Congreso Ecuatoriano de Acuicultura', Guayaquil, p 229-232

Submitted: August 7, 2000; Accepted: October 16, 2000 Proofs received from author(s): January 22, 2001 